\title{
CAROTENOIDS IN FOODS
}

\author{
Tatjana Pavlova ${ }^{1}$, Viktorija Stamatovska ${ }^{1}$, Ivan Dimov $^{2}$, Gjore Nakov ${ }^{3} \&$ Tatjana \\ Kalevska ${ }^{1}$ \\ ${ }^{1}$ Faculty of Technology and Technical Sciences, University St. Kliment Ohridski of Bitola, \\ Dimitar Vlahov bb, 1400 Veles, Republic of Macedonia \\ e-mail: tatjanapavlova15@yahoo.com, vikistam2@gmail.com, tkalevska@gmail.com \\ ${ }^{2}$ Faculty of Technics and Technologies of Yambol, Trakia University of Stara Zagora \\ Graf Ignatiev 38, 8600 Yambol, Bulgaria, e-mail: ivendi_81@abv.bg \\ ${ }^{3}$ Department of Biotechnology and Food Technologies, University of Ruse "Angel Kanchev", \\ Branch Razgrad, Aprilsko vastanie Blvd. 47, 7200 Razgrad, Bulgaria \\ e-mail: gore_nakov@hotmail.com
}

\begin{abstract}
Carotenoids are pigments giving the yellow, orange and red colours to the fruits, vegetables, as well as products manufacturing from them. They belong to bio-active compound, being of special interest for the food scientists, nutritionists and food industry due to its positive effect on human health. They function as secondary antioxidants in the food, with ability for significant reduction of the oxygen. Their provitamin role is also very important. Human body has no ability to synthesize them, so those compounds should be taken through diet. Carotenoids are widespread in plants, but they could be found in poultry, eggs and fish, as well. The most common carotenoids in the food include $\beta$-carotene, lycopene, lutein, zeaxanthin and astaxanthin.
\end{abstract}

Keywords: carotenoids, pigments, $\beta$-carotene, lycopene, lutein, zeaxanthin, astaxanthin, food.

\section{INTRODUCTION}

Carotenoids are organic pigments (mainly $\mathrm{C}_{40}$ lipophilic isoprenoids) naturally occurring in the chromoplasts of plants and some other photosynthetic organisms such as algae, as well as in some non-photosynthetic bacteria and fungi, where they have diverse and important functions and actions. They are responsible for colours ranging from red to orange, yellow, and colorless (e.g. phytoene, phytofluene), with variations reflected in many fruits, vegetables, and flowers $[18,36,20]$. Carotenoids can also be present, to a lesser extent, in eggs, poultry, and fish because the animals are typically fed plant and algal products; e.g., the zeaxanthin in chicken originates from maize in the poultry feed [47]. Carotenoids as such are mainly responsible for the yellow to red colours in birds, fish, reptiles and insects. They can also form complexes with proteins and lipoproteins producing an even wider range of colours, including green and blue hues [5, 29]. Carotenoids in plants and algae play a key role in photosynthesis as they absorb light energy and also protect chlorophyll from photodamage and oxidation caused by light and oxygen [5].

The carotenoids of fruit, vegetables and animal products are insoluble in water, and are usually fat-soluble (partially soluble in plant oils, animal fat and biological membranes) [26, 20].

Most of them can be described by the chemical formula $\mathrm{C}_{40} \mathrm{H}_{56} \mathrm{O}_{n}$, with $n$ ranging from 0 to 6 . They are split, according to their chemical structure, into 2 classes: carotenes (nonoxygenated carotenoids; containing only carbon and hydrogen atoms i.e. $n=0$ ) and xanthophylls (oxygenated carotenoids; which carry at least one oxygen atom i.e. $n>0$ ) [7, 20]. Carotenes include $\beta$-carotene, $\alpha$-carotene and lycopene and xanthophylls include lutein, fucoxanthin, canthaxanthin, zeaxanthin, beta-criptoxanthin, capsorubin, and astaxanthin [33,

IRTIIE Vol. 6, No. 4, 2018 ISSN 1314-8788 (print), ISSN 1314-8796 (online), doi: 10.15547/artte.2018.04.006 
23]. Different carotenoids are derived essentially by modifications in the base structure by cyclization of the end groups and by the introduction of oxygen functions giving them their characteristic colors and antioxidant properties [38].

Structures of some common carotenoids are shown in Figure 1.

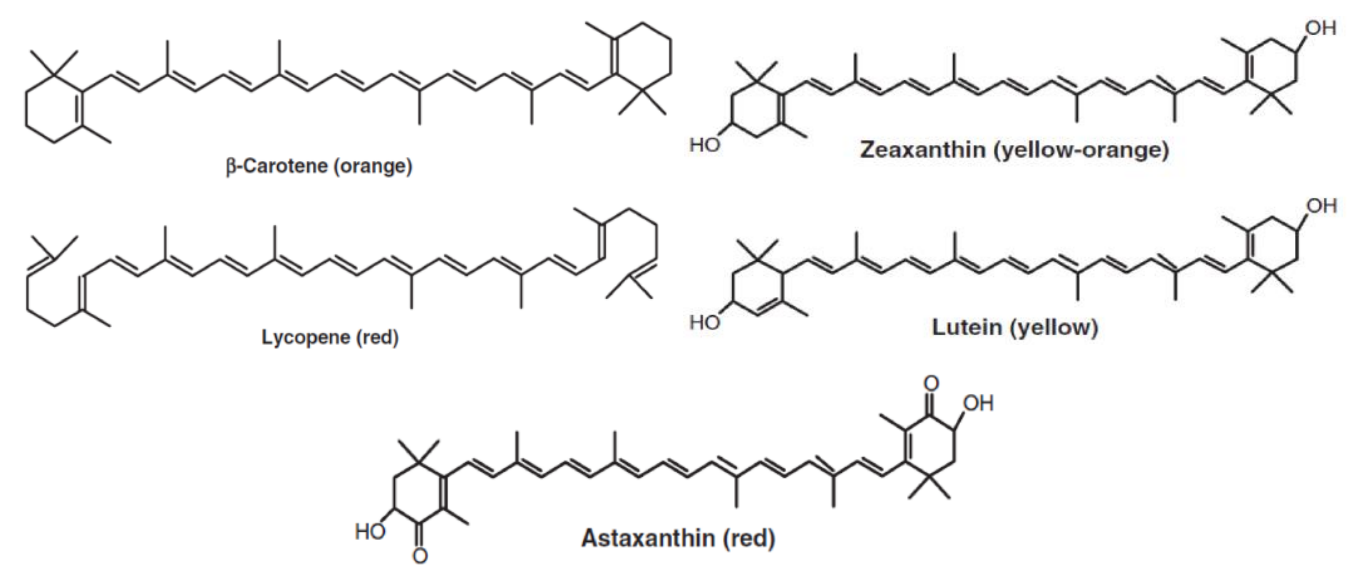

Figure 1. Structures of some carotenoids [18]

In foods (including fruits and vegetables), carotenoids are important quality parameters, because they impart attractive colors such as yellow, orange, and red. In humans, some carotenoids, are precursors to vitamin A, and several are potent antioxidants [18]. Provitamin $A$ carotenoids are $\beta$-carotene, $\alpha$-carotene and cryptoxanthins, while non-provitamin $A$ carotenoids are lutein, zeaxanthin and lycopene [7]. Carotenoids have been thought to prevent degenerative diseases such as cancer, atherosclerosis and age-related macular degeneration in humans, due to their potential to suppress oxidative lesions by scavenging peroxy radicals and quenching singlet oxygen. Other various biological activities of carotenoids such as immune enhancement, anti-inflammation, and antiobesity are also thought to benefit human health $[8,35]$.

\section{CHARACTERISTIC OF SOME CAROTENOIDS}

$\boldsymbol{\beta}$-Carotene. The bicyclic $\beta$-carotene is the most widespread of all carotenoids in foods, either as a minor or as the major constituent $[40,18]$. It is an organic compound, a redorange pigmented terpenoid that abounds in plants and fruits [15]. Being a polyene compound, derived from the acyclic structure, $\mathrm{C}_{40} \mathrm{H}_{56}$ possesses a long chain of conjugated double bonds. The $\beta$-carotene molecule contains two $\beta$-ionic rings. Theoretically, the cleavage of that chain at $-\mathrm{C} 15=\mathrm{C} 15^{\prime}-$ position provides two retinol molecules. $\beta$-carotene reveals the highest bioactivity as vitamin A precursor [9]. Major sources of dietary $\beta$-carotene include green leafy vegetables as well as orange and yellow fruits and vegetables, such as carrots, sweet potatoes, mangoes, pumpkin, spinach, apricots, pepper, cantaloupe, lettuce, and tomato paste [28, 7, 37].

Lycopene. Lycopene is a bright red bioactive lipid soluble carotenoid that is synthesized in various isomeric forms by some microorganisms and plants, but not by animals and human [15]. It is a highly unsaturated open straight chain hydrocarbon consisting of 11 conjugated double bonds in the center part of the molecule and 2 unconjugated double bonds at each end. Unlike $\beta$-carotene, a lycopene is not precursor of vitamin A. Because of the unsaturated nature of lycopene it is considered to be a potent antioxidant and a singlet oxygen quencher

IRTIIE Vol. 6, No. 4, 2018 ISSN 1314-8788 (print), ISSN 1314-8796 (online), doi: 10.15547/artte.2018.04.006 


\section{ARTTIE $Y^{2}$}

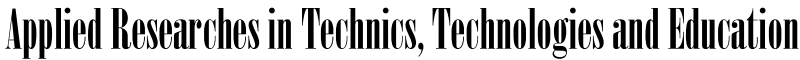

Journal of the Faculty of Technics and Technologies, Trakia University https://sites.google.com/a/trakia-uni.bg/artte/

$[45,38]$. Lycopene is the principal pigment of many red-fleshed fruits and fruit vegetables, such as tomato, watermelon, red-fleshed papaya and guava, and red or pink grapefruit [40, 18].

Lutein and zeaxanthin. Lutein and zeaxanthin are xanthophyll carotenoids that impart yellow or orange color to various foods, such as yellow corn, egg yolk, orange juice, cantaloupe, and other fruits, but particularly found in dark-green leafy vegetables such as kale, turnip greens, spinach, parsley and broccoli [1,23]. The structures of lutein and zeaxanthin are characterized by the presence of a hydroxyl group attached to each of the 2 terminal $\beta$-ionone rings in the molecule. Lutein and zeaxanthin are isomers, but not stereoisomers, which differ in the location of a double bond unsaturation in the end ring. They are not precursors of vitamin A $[39,1]$.

Astaxanthin. Astaxanthin, a xanthophyll carotenoid subclass, has a unique structure featured by the presence of hydroxyl and keto moieties on both end of its polyene chain. This structural property of astaxanthin confers a great antioxidant activity and allows it to align in the cell membrane for various biological activities [25, 49]. Astaxanthin is a red soluble pigment, abundant in the marine world, where it can be found in microalgae (Haematococcus pluvialis), plankton, fish such as salmon and trout, and most crustaceans (e.g., shrimp, lobster, and crab). Humans are not able to synthesize astaxanthin and need to take it from

food. Astaxanthin cannot be converted to vitamin A. A large proportion of astaxanthin is manufactured mainly by chemical synthesis. [40, 44, 23]

\section{CAROTENOIDS IN FOODS}

The carotenoid composition of foods varies qualitatively and quantitatively. Typically a food would have one to five major carotenoids with a series of minor carotenoids in trace or very small amounts. In a given food qualitative and, especially, quantitative differences also exist due to factors such as cultivar/ variety, stage of maturity, climate/geographic site of production, part of the plant utilized, conditions during agricultural production, post-harvest handling, storage conditions, and processing. During processing, isomerization of transcarotenoids to the cis-forms occurs, with consequent alteration of the carotenoids bioavailability and bioconversion. The principal cause of carotenoid loss during processing and storage of food is enzymatic or non-enzymatic oxidation [41, 42]. In the literature, controversial data on carotenoid stability during thermal processing are reported. These contrasting results may depend on the different genotypes evaluated and on the temperature and time adopted in the processing methods [19].

Green leafy vegetables are good sources of carotenoids (lutein, $\beta$-carotene, violaxanthin and neoxanthin) [13].The composition of carotenoids in leafy vegetables markedly varies with variety and geographic conditions, as well as post-harvest handling practices [21]. Cooking affected the carotenoids content of vegetables depend on the vegetable, types of cooking method and interaction between cooking method and types of vegetable [14]. Corn is one of the most widely cultivated cereals in the world. The major carotenoids found in corn grains are lutein, zeaxanthin, and $\alpha$-cryptoxanthin. Corn is readily available as fresh, canned or frozen. Processing of corn is used to increase its shelf life but as a consequence, a significant loss of nutrients may occur via heat degradation or leaching [43, 27, 46]. Carrots are the most popular and wide-spread of all root vegetables and have the highest carotenoid content among foods. Carrots are said to be a major source of $\beta$-carotene [32, 10]. They are available as a fresh product all the year round, but also are used in the food industry for the production of highly processed food (children's products, vegetable and vegetable-fruit juices), in drying and especially in the freezing industry [24]. Tomatoes and various tomato products (tomato pulp, ketchup, concentrated tomato paste, dried tomato slices, tomato sauce and juice) are rich sources of carotenoids-principally lycopene, followed by $\beta$ -

IRTIIE Vol. 6, No. 4, 2018 ISSN 1314-8788 (print), ISSN 1314-8796 (online), doi: 10.15547/artte.2018.04.006 


\section{ARTTIE $Y$}

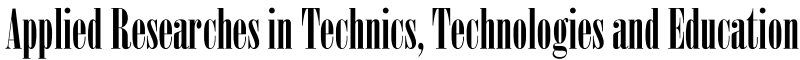

Journal of the Faculty of Technics and Technologies, Trakia University https://sites.google.com/a/trakia-uni.bg/artte/

carotene and lutein $[48,22,4,2,16,34,17,50]$.

Many researchers have analyzed carotenoid content in fresh and processed food. In a study on the carotenoid composition of four typologies of tomatoes, different values were provided by Leonardi et al., (2000) [30]. The content of the lycopene in tomatoes was from 0.11 to $10.80 \mathrm{mg} / 100 \mathrm{~g}$ of fresh weight (FW) and of $\beta$-carotene from 0.08 to $1.05 \mathrm{mg} / 100 \mathrm{~g} \mathrm{FW}$. In a more recent study, Zanfini et al., (2017) [50] states that the content of lycopene in tomato fruits is in the range of $1.02 \mu \mathrm{g} / \mathrm{g}$ to $184.42 \mu \mathrm{g} / \mathrm{g} \mathrm{FW}$, of $\beta$-carotene ranged from $2.60 \mu \mathrm{g} / \mathrm{g}$ to $64.81 \mu \mathrm{g} / \mathrm{g} \mathrm{FW}$, while lutein $0.08 \mu \mathrm{g} / \mathrm{g}$ to $1.12 \mu \mathrm{g} / \mathrm{g} \mathrm{FW}$. Wawrzyniak et al. (2005) [48] analyzed the lycopene content of tomatoes as well as tomato products and other products available on the Polish market. They reported that lycopene content of fresh tomatoes ranged from 1.21 to $6.43 \mathrm{mg} / 100 \mathrm{~g}$, the average content of tomato pastes was 38.88 $\mathrm{mg} / 100 \mathrm{~g}$, of ketchup $-11.12 \mathrm{mg} / 100 \mathrm{~g}$, and of tomato juices $-7.05 \mathrm{mg} / 100 \mathrm{~g}$. Also, Alda et al. (2009) [4] evaluated the lycopene contents of fresh tomatoes and various commonly consumed tomato products (tomato paste, tomato sauce, tomato ketchup, spaghetti sauce) from the Romanian market. The results showed that lycopene content of samples of fresh tomatoes was approximately $12 \mathrm{mg} / 100 \mathrm{~g}$, in tomato paste approximately $16 \mathrm{mg} / 100 \mathrm{~g}$, in tomato boild sauce approximately $4 \mathrm{mg} / 100 \mathrm{~g}$, in tomato ketchup $17 \mathrm{mg} / 100 \mathrm{~g}$ and in spaghetti sauce $16 \mathrm{mg} / 100 \mathrm{~g}$. Gama et al., (2006) [22] studied tomato and tomato products (tomato pulp and ketchup) and concluded that lycopene is the most abundant carotenoid, followed by $\beta$-carotene. They also contained other carotenoids in much smaller amounts (lycoxanthin, zeaxanthin, anteraxanthin, lutein). Other data about carotenoids in tomato and canned products were reported by D'Evoli et al., (2013) [17], where the predominant carotenoid detected in all samples was lycopene, with values ranging from $5.12 \mathrm{mg} / 100 \mathrm{~g}$ $\mathrm{FW}$ in the raw sample to $11.60 \mathrm{mg} / 100 \mathrm{~g} \mathrm{FW}$ in the canned sample. $\beta$-Carotene and lutein occurred in lower amounts.

Cardoso et al., (2009) [11], investigated the $\alpha$ - and $\beta$-carotene content of four leafy vegetables (large-leaved and hydroponic watercress, curly and smooth lettuce, kale, and spinach) sold at markets in Brazil, during spring and winter. $\alpha$-Carotene was detected in all samples sold during spring, but was only present in a few samples of smooth and curly lettuce and kale in winter. $\beta$-Carotene was found in marked quantities in all leafy vegetables analyzed. Mean $\beta$-carotene content was $7544,8751,2584,2792,8193$, and $5338 \mathrm{mg} / 100 \mathrm{~g}$ in large-leaved and hydroponic watercress, smooth and curly lettuce, kale and spinach, respectively. Before, Ahamad et al. (2007) [3] reported that dark green vegetables contained more $\beta$-carotene as compared to other vegetables e.g. spinach contained $9940 \mu \mathrm{g} / 100 \mathrm{~g}$, followed by mint, kulfa, lettuce and ladyfinger that were all dark green in appearance, apart from carrot that contains a maximum amount of $\beta$-carotene $(11210 \mu \mathrm{g} / 100 \mathrm{~g})$. Djuikwo et al. (2011) [21] identified carotenoids present in processed and unprocessed tropical leafy vegetables. They ascertained the presence of lutein, $\alpha$-carotene, zeaxanthin, $\beta$ cryptoxanthin, $\beta$-carotene (all-trans, 13-cis, and 9-cis), which varied by species. Traditional preparation and processing procedures led to significant losses of carotenoids and $\beta$ carotene was most affected during sun-drying. The effect of different domestic cooking methods (boiling and stir-frying) on carotenoids retention in commonly consumed Malaysian leafy vegetables was analyzed by Chang et al. (2013) [14].The lutein content was in the order of spinach $>$ tapioca shoots $>$ Ceylon spinach $>$ red spinach $>$ Chinese cabbage $>$ white spinach $>$ swamp cabbage. $\beta$-carotene was in the order of spinach $>$ tapioca shoots $>$ Ceylon spinach $>$ red spinach $>$ white spinach $>$ Chinese cabbage $>$ swamp cabbage. Also, discovered that stir-frying had reduced lutein content for all vegetables, while the effect of boiling for lutein varied with different vegetables at both cooking durations. Boiling for 8 min increased retention of $\beta$-carotene in all vegetables except for Chinese cabbage and spinach compared with $4 \mathrm{~min}$, while stir-frying generally increased the retention of $\beta$-carotene for all vegetables 2-3 times except for spinach. In a more recent study, Chandra-Hioe et al., (2017)

IRTIIE Vol. 6, No. 4, 2018 ISSN 1314-8788 (print), ISSN 1314-8796 (online), doi: 10.15547/artte.2018.04.006 


\section{ARTTIE $Y$}

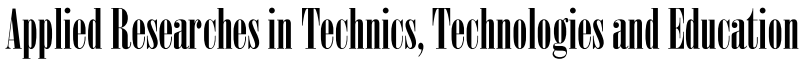

Journal of the Faculty of Technics and Technologies, Trakia University https://sites.google.com/a/trakia-uni.bg/artte/

[12] determined the content of lutein and $\beta$-carotene in Asian leafy vegetables (Chinese mustard, water spinach, Chinese spinach, coriander, Chinese flowering cabbage, Chinese broccoli and Chinese white cabbage). The range of lutein in the vegetable samples was between 694 and $5919 \mu \mathrm{g} / 100 \mathrm{~g}$, where lutein was lowest in white cabbage and highest in coriander. The highest $\beta$-carotene, $6604 \mu \mathrm{g} / 100 \mathrm{~g}$, was determined in Chinese broccoli, and the lowest, $1974 \mu \mathrm{g} / 100 \mathrm{~g}$, in Chinese mustard samples.

Scott and Eldridge (2005) [43] found that major carotenoids in sweet corn were lutein and zeaxanthin, and to a lesser extent, $\alpha-, \beta$-cryptoxanthin, $\alpha-$, and $\beta$-carotene. Bacchetti et al. (2013) [6] evaluated the levels of carotenoids and antioxidant properties of different types of corn. They reported that the major carotenoids identified by HPLC were in the order zeaxanthin $>\alpha$-cryptoxanthin $>$ lutein $>\beta$-carotene $>\alpha$-carotene $>\beta$-cryptoxanthin. In a more recent study, Song et al. (2016) [46] reported that the main carotenoid compounds of sweet and waxy corn grains were all-trans-lutein, all-trans zeaxanthin, all-trans- $\alpha$-cryptoxanthin, alltrans- $\beta$ - cryptoxanthin, and violaxanthin. Carotenoid profiles were different among the corn genotypes, but lutein (ranging from 0.14 to $9.80 \mu \mathrm{g} / \mathrm{g}$ ) and zeaxanthin $(0.83$ to $10.86 \mu \mathrm{g} / \mathrm{g}$ ) were the most abundant carotenoids for all immature and mature samples. Mamatha et al. (2012) [31], suggested that blanching could increase the levels of lutein and zeaxanthin in corn and vegetables. The effects of domestic cooking methods and frozen storage on lutein, zeaxanthin, $\beta$-cryptoxanthin, $\beta$-carotene and total carotenoid contents of five sweet corn cultivars of different ear size and kernels corn were investigated by Junpatiw et al. (2013) [27]. Lutein and zeaxanthin were the predominant carotenoids in raw, cooked and frozen sweet corns. The results demonstrated that domestic cooking (steaming and boiling) increased the concentration of total carotenoids (41.33-179.93\%), lutein (35.51-232.18\%), zeaxanthin (48.12-457.16\%), $\beta$-cryptoxanthin $(22.35-405.03 \%)$ and $\beta$-carotene (15.82$88.16 \%)$ for all cultivars, except the Hybrix3. The increases in lutein, zeaxanthin, $\beta$ cryptoxanthin and $\beta$-carotene after cooking were higher in the small-ear corn varieties than those of the big-ear corn varieties. All corn cultivars showed decreases in lutein, zeaxanthin, $\beta$-cryptoxanthin and $\beta$-carotene contents during frozen storage.

In the literature can be found many more information about the presence of carotenoids in different foods. Previously presented represent just a fraction of them.

\section{CONCLUSIONS}

Carotenoids are a class of natural pigments, responsible for the red, orange and yellow color in foods. As it can be appreciated from this review, they have been studied for a number of years. Mostly explored among them are $\alpha$-and $\beta$-carotene, lycopene, zeaxanthin, lutein and astaxanthin. Numerous factors may interfere with the carotenoid content of foods, such as maturation stage, differences between varieties, climate conditions, the effect of agrochemicals, cultivation conditions, post-harvest handling, exposure to light, storage and processing conditions. Food carotenoids will continue to be intensely investigated in the coming years. The need for determining the carotenoid composition of foods is increasingly recognized, because of the natural variation in carotenoid composition, data obtained in one country may not be relevant in another.

\section{ACKNOWLEDGMENTS}

The study was supported by contract of University of Ruse "Angel Kanchev", № BG05M2OP001-2.009-0011-C01, "Support for the development of human resources for research and innovation at the University of Ruse "Angel Kanchev". The project is funded with support from the Operational Program „Science and Education for Smart Growth 2014 2020" financed by the European Social Fund of the European Union.

IRTTIE Vol. 6, No. 4, 2018 ISSN 1314-8788 (print), ISSN 1314-8796 (online), doi: 10.15547/artte.2018.04.006 


\section{ARTTIE $Y$}

Ipplied Resseirlohes in Technics, Technologies and Bductation

Journal of the Faculty of Technics and Technologies, Trakia University https://sites.google.com/a/trakia-uni.bg/artte/

\section{REFERENCES}

[1] Abdel-Aal M. E., Akhtar H., Zaheer K. \& Rashida A. (2013). Dietary Sources of Lutein and Zeaxanthin Carotenoids and Their Role in Eye Health. Nutrients, Vol. 5, (2013), pp. 1169-1185.

[2] Adalid.M. A., Rosello S. \& Nuez F. (2010). Evaluation and selection of tomato accessions (Solanum section Lycopersicon) for content of lycopene, $\beta$-carotene and ascorbic acid. J. Food Comp. Anal., Vol. 23, (2010), pp. 613-618.

[3] Ahamad M. N., Saleemullah M., Shah H. U., Khalil I. A., \& Saljoqi, A. U. R. (2007). Determination of beta carotene content in fresh vegetables using high performance liquid chromatography. Sarhad Journal of Agriculture, Vol. 23, No. 3, (2007), pp. 767770.

[4] Alda M. L., Gogoaşă I., Bordean DM. , Gergen I., Alda S., Moldovan C. \& Niţă L. (2009). Lycopene content of tomatoes and tomato products. Journal of Agroalimentary Processes and Technologies, Vol. 15, No. 4, (2009), pp. 540-542.

[5] Amaya E., Becquet P., Carné S., Peris S. \& Miralles P., (2014). Carotenoids in Animal Nutrition. Fefana Publication, Belgium (2014).

[6] Bacchetti T. Masciangelo S. Micheletti A. \& Ferretti G. (2013). Carotenoids, Phenolic Compounds and Antioxidant Capacity of Five Local Italian Corn (Zea Mays L.) Kernels. J Nutr Food Sci, Vol. 3, No. 6, (2013): 237.

[7] Bakan E., Akbulut T. Z. \& İnanç L.A. (2014). Carotenoids in Foods and their Effects on Human Health, Akademik Gıda, Vol. 12, No. 2, (2014), pp. 61-68.

[8] Bernal J., Mendiola J.A., Ibáñez, E. \& Cifuentes A. (2011). Advanced analysis of nutraceuticals. J. Pharm. Biomed. Anal., Vol. 55, (2011), pp. 758-774.

[9] Bogacz-Radomska L. \& Harasym J. (2018). $\beta$-Carotene-properties and production methods. Food Quality and Safety, Vol. 2, (2018), pp. 69-74.

[10] Bozalan K. N. \& Karadeniz F. (2011). Carotenoid Profile, Total Phenolic Content, and Antioxidant Activity of Carrots. International Journal of Food Properties. Vol. 14, No. 5, (2011), pp. 1060-1068.

[11] Cardoso C. P., Della Lucia M. C., Stringheta C.P., Chaves P. B. J. \& Pinheiro-Sant'Ana M. H. (2009). Carotene and provitamin A content of vegetables sold in Viçosa, MG, Brazil, during spring and winter. Brazilian Journal of Pharmaceutical Sciences, Vol. 45, No. 3, (2009), pp. 527-537.

[12] Chandra-Hioe M.V., Rahman H.H. \& Arcot J. (2017). Lutein and $\beta$-Carotene in Selected Asian Leafy Vegetables. J Food Chem Nanotechol, Vol. 3, No. 3, (2017), pp. 93-97.

[13] Chandrika U. G., Janz R. E. \& Warnasuriya N. D. (2005). Analysis of $\beta$-carotene and lutein in some leafy vegetables and effect of cooking on serum vitamin A formation from Alternanthera sessilis (sinh. Mukunuwanna). J. Natn. Sci. Foundation Sri Lamka, Vol. 33, No. 2, (2005), pp. 141-145.

[14] Chang S.K., Nagendra P. K. \& Amin I. (2013). Carotenoids retention in leafy vegetables based on cooking methods. International Food Research Journal, Vol. 20, No. 1, (2013), pp. 457-465.

[15] Charles N. I., Jude O. I., James E. O. \& Tochukwu C.E. (2014). Effect of Thermal Processing on Lycopene, Beta-Carotene and Vitamin C Content of Tomato [Var.UC82B]. Journal of Food and Nutrition Sciences, Vol. 2, No. 3, (2014), pp. 87-92.

[16] Cucu T., Huvaere K., Van Den Bergh MA., Vinkx C. \& Joris Van Loco V. J. (2012). A Simple and Fast HPLC Method to Determine Lycopene in Foods, Food Anal. Methods, Vol. 5, (2012), pp. 1221-1228.

[17] D’Evoli L., Lombardi-Boccia G. \& Lucarini M. (2013). Influence of Heat Treatments on Carotenoid Content of Cherry Tomatoes. Foods, Vol. 2, (2013), pp. 352-363. 
[18] de la Rosa A. L., Alvarez-Parrilla E. \& Gonzalez-Aguilar A. G. (2010). Fruit and vegetable phytochemicals : chemistry, nutritional value and stability. Wiley-Blackwell, USA, (2010).

[19] Del Giudice R., Petruk G., Raiola A., Barone A., Monti D.M. \& Rigano M.M. (2017). Carotenoids in fresh and processed tomato (Solanum lycopersicum) fruits protect cells from oxidative stress injury. J Sci Food Agric., Vol. 97, No. 5, (2017), pp. 1616-1623.

[20] Desmarchelier C. \& Borel P. (2017). Overview of carotenoid bioavailability determinants: From dietary factors to host genetic variations. Trends in Food Science \& Technology, Vol. 69, No. B, (2017), pp. 270-280.

[21] Djuikwo V., Ejoh R., Gouado I., Mbofung C. \& Tanumihardjo S. (2011). Determination of Major Carotenoids in Processed Tropical Leafy Vegetables Indigenous to Africa. Food and Nutrition Sciences, Vol. 2, No. 8, (2011), pp. 793-802.

[22] Gama J. J. T., Tadiotti A. C., \& de Sylos. C. M. (2006). Comparison of carotenoid content in tomato, tomato pulp and ketchup by liquid chromatography. Alim. Nutr., Araraquara, Vol. 17, No. 4, (2006), pp. 353-358.

[23] Gammone A. M., Riccioni G. \& D'Orazio N. (2014). Carotenoids: potential allies of cardiovascular health?. Food \& Nutrition Research, Vol. 59, (2014): 26762.

[24] Gębczyński P. (2006). Content of selected antioxidative compounds in raw carrot and in frozen product prepared for consumption. Electronic Journal of Polish Agricultural Universities, Vol. 9, No. 3, http://www.ejpau.media.pl/volume9/issue3/art-03.html (accessed June 15, 2006).

[25] Higuera-Ciapara I., Félix-Valenzuela L. \& Goycoolea F.M. (2006). Astaxanthin: a review of its chemistry and applications. Crit Rev Food Sci Nutr., Vol.46, (2006), pp. 185-196.

[26] Jaswir I., Noviendri D., Hasrini F.R. \& Octavianti F. (2011). Carotenoids: Sources, medicinal properties and their application in food and nutraceutical industry. Review Journal of Medicinal Plants Research, Vol. 5, No. 33, (2011), pp. 7119-7131.

[27] Junpatiw A., Lertrat K., Lomthaisong K. \& Tangwongchai R. (2013). Effects of steaming, boiling and frozen storage on carotenoid contents of various sweet corn cultivars. International Food Research Journal, Vol. 20, No. 5, (2013), pp. 2219-2225.

[28] Krinsky I.N. \& Johnson J.E. (2005). Carotenoid actions and their relation to health and disease. Molecular Aspects of Medicine, Vol. 26, (2005), pp. 459-516.

[29] Lachman J., Hamouz K., Orsák M. \& Kotíková Z. (2016). Carotenoids in potatoes - a short overview. Plant Soil Environ., Vol. 62, No. 10, (2016), pp. 474-481.

[30] Leonardi C., Ambrosino, P., Esposito, F. \& Fogliano, V. (2000). Antioxidative activity and carotenoid and tomatine contents in different typologies of fresh consumption tomatoes. J. Agric. Food Chem., Vol.48, (2000), pp. 4723-4727.

[31] Mamatha B. S., Arunkumar R. \& Baskaran V. (2012). Effect of processing on major carotenoid levels in corn (Zea mays) and selected vegetables: Bioavailability of Lutein and Zeaxanthin from processed corn in Mice. Food Bioprocess Technology, Vol. 5, No. 4, (2012), pp.1355-1365.

[32] Matějková J. \& Petříková K. (2010). Variation in Content of Carotenoids and Vitamin C in Carrots. Not Sci Biol, Vol. 2, No. 4, (2010), pp. 88-91.

[33] McNulty H., Jacob F. R. \& Mason P. R. (2008). Biologic activity of carotenoids related to distinct membrane physicochemical interactions. Am J Cardiol, Vol. 101, (2008), pp. 20D-29D.

[34] Mendelova A., Fikselova M., \& Mendel L. (2013). Carotenoids and lycopene content in fresh and dried tomato fruits and tomato juice. Acta Universitatis Agriculturae et Silviculturae Mendelianae Brunensis, Vol. LXI, No. 5, (2013), pp.1329-1337.

[35] Nagao A. (2014). Bioavailability of Dietary Carotenoids: Intestinal Absorption and Metabolism. JARQ, Vol. 48, No. 4, (2014), pp. 385-391. 
[36] Nisar N., Li L., Lu S., Khin C. N. \& Pogson J. B., (2015). Carotenoid Metabolism in Plants. Mol. Plant., Vol. 8, (2015), pp. 68-82.

[37] Pritwani R. \& Mathur P. (2017). B-carotene Content of Some Commonly Consumed Vegetables and Fruits Available in Delhi, India. J Nutr Food Sci, Vol. 7, No. 5, (2017): 625.

[38] Rao V. A. \& Rao G. L. (2007). Carotenoids and human health. Pharmacological Research, Vol. 55, (2007), pp. 207-221.

[39] Ribaya-Mercado D. J. \& Blumberg B. J. (2004). Lutein and Zeaxanthin and Their Potential Roles in Disease Prevention. Journal of the American College of Nutrition, Vol. 23, No. 6, (2004), pp. 567S-587S.

[40] Rodriguez-Amaya B. D. (2001). A Guide to Carotenoid Analysis in Foods. ILSI Press, Washington, (2001).

[41] Rodriguez-Amaya B.D. \& Kimura M. (2004). Harvest Plus Handbook for Carotenoid Analysis. Harvest Plus Technical Monograph 2, DC and Cali: International Food Policy Research Institute (IFPRI) and International Center for Tropical Agriculture (CIAT), Washington, (2004).

[42] Rodriguez-Amayal B. D, Rodriguez B. E. \& Amaya-Farfanl J. (2006). Advances in Food Carotenoid Research: Chemical and Technological Aspects, Implications in Human Health. Ma1 J Nutr, Vol. 12, No. 1, (2006), pp. 101-121.

[43] Scott E. C. \& Eldridge L. A. (2005). Comparison of carotenoid content in fresh, frozen and canned corn. Journal of Food Composition and Analysis, Vol. 18, No. 6, (2005), pp. 551-559.

[44] Seabra J. A. M. L. \& Pedrosa C. F. L. (2010). Astaxanthin: structural and functional aspects. Rev. Nutr., Campinas, Vol. 23, No. 6, (2010), pp. 1041-1050.

[45] Shi J., Qu Q., Kakuda Y., Yeung D. \& Jiang Y. (2004). Stability and Synergistic Effect of Antioxidative Properties of Lycopene and Other Active Components. Critical Reviews in Food Science and Nutrition, Vol. 44, (2004), pp. 559-573.

[46] Song J., Li D., He M., Chen J. \& Liu C. (2016). Comparison of Carotenoid Composition in Immature and Mature Grains of Corn (Zea Mays L.) Varieties. International Journal of Food Properties, Vol. 19, No.2, (2016), pp. 351-358.

[47] Voutilainen S., Nurmi T., Mursu J. \& Rissanen H.T. (2006). Carotenoids and cardiovascular health. Am J Clin Nutr, Vol. 83, (2006), pp. 1265-1271.

[48] Wawrzyniak A., Marciniak A. \& Rajewska J. (2005). Lycopene content of selected foods available on the Polish market and estimation of its intake. Pol. J. Food Nutr. Sci., Vol.14/55, No. 2, (2005), pp. 195-200.

[49] Yang Y., Kim B. \& Lee J.Y. (2013). Astaxanthin Structure, Metabolism, and Health Benefits. J Hum Nutr Food Sci, Vol. 1, (2013): 1003.

[50] Zanfini A., Franchi G.G., Massarelli P., Corbini G. \& Dreassi E. (2017). Phenolic compounds, carotenoids and antioxidant activity in five tomato (Lycopersicon Esculentum Mill.) cultivar. Ital. J. Food Sci., Vol. 29, (2017), pp. 90-99. 